\title{
HUMAN RIGHTS, CRIMINAL JUSTICE AND THE FUTURE OF THE COMMON LAW
}

\author{
John Jackson, School of Law, Queen's University Belfast*
}

\section{Introduction}

The considerable attention given to human rights in recent years raises the question whether the common law is being overshadowed by human rights jurisprudence. In the United Kingdom the enactment of the Human Rights Act 1998 has meant that increased prominence has been given to human rights points. In a recent lecture Brice Dickson has noted that in the last five years one in four of the 320 cases decided by the House of Lords involved a substantial examination of a Human Rights Act point and last year the figure was one in three. ${ }^{1}$ Although Dickson refers to human rights not protected by the Human Rights Act and specifically to human rights protected by the common law of England and Northern Ireland, it would seem that there were by contrast only a handful of cases which raised human rights issues not involving the Human Rights Act. $^{2}$ Of course, these statistics do not by themselves illustrate that the common law has been overshadowed by the Human Rights Act. With the passage of an Act of such fundamental constitutional significance as the Human Rights Act which substantially incorporates the European Convention on Human Rights into UK law, it was inevitable that there would be many human rights points which would be tested in the courts. This does not mean that the common law does not continue to provide the bedrock for many of our fundamental liberties and guarantees against arbitrary government.

Another point is that it is misleading to set up the common and human rights law in some kind of opposition to each other. In his masterly account of the formation of the Convention, Brian Simpson has shown how in many respects the final draft was a triumph for common lawyers as they succeeded in enshrining many specific rights that were already constituted in the common law, although he illustrates how the establishment of a Court with the responsibility for developing a jurisprudence of rights over and above that developed by the member states was more a triumph for a civil law approach. ${ }^{3}$ In his judgment in the House of Lords case upholding the right of Belmarsh detainees not to be detained without trial, Lord Hoffmann reminded us that the United Kingdom subscribed to the Convention because

* Thanks are due to Gordon Anthony, Brice Dickson and Sean Doran for their comments on an earlier draft. The errors that remain are the sole responsibility of the author.

1 B. Dickson, "Safe in Their Hands? The Law Lords and Human Rights" (2006) The Stephen Livingstone Memorial Lecture, available at www.law.qub.ac.uk/ humanrts/hrevents/bdickson06.doc.

2 The examples he refers to are, in his words, "outstanding examples. . . of principles derived from customary international human rights law" rather than examples of the application of common law.

3 A. W. B. Simpson, Human Rights and the End of Empire (2001), especially chaps. 13 and 14. 
it sets out the rights which British subjects enjoyed under common law. ${ }^{4}$ Freedom from arbitrary arrest and detention, he declared, was not some special doctrine of European law, but a "quintessentially British" liberty. ${ }^{5}$ In a similar fashion some of the basic principles of fairness contained in article 6 of the European Convention such as the right to an independent and impartial tribunal and the right to be heard derive from the common law principles of natural justice. ${ }^{6}$ Others such as the presumption of innocence and the privilege against self-incrimination have long been hallmarks of the common law criminal trial. ${ }^{7}$

Albeit that many common law rights have been subsumed under the European Convention rights, however, the increasing attention given to the human rights standards under the Convention raises the question whether these are the standards that will now take the centre stage of our jurisprudence with the common law relegated to a much less significant role. For many years, citizens in common law countries have looked to the common law for protection against arbitrary abuse of power and for upholding the rule of law. Nowhere has this been more evident than in the field of criminal justice where the courts have used remedies such as habeas corpus and, more recently, abuse of process to protect the citizen from governmental abuse. ${ }^{8}$ Now under sections 2 and 3 of Human Rights Act the courts must take into account the Strasbourg jurisprudence and so far as possible read and give effect to legislation in a way which is compatible with Convention rights. This raises the question whether the torch for protecting our "fundamental freedoms" - the term used in the full title of the European Convention - has passed from the common law to the human rights standards of the Convention. ${ }^{9}$

${ }^{4} A$ and others v Secretary of State for the Home Department; $X$ and another $\mathrm{v}$ Secretary of State for the Home Department [2004] UKHL 56.

5 ibid., para.88. See also T. Poole, "Harnessing the Power of the Past? Lord Hoffman and the Belmarsh Detainees Case" (2005) 32 J.L.S. 534

6 "The common law principles of natural justice anticipated by many years the concept of a fair trial that has been elaborated by [art 6]": Bow Spring (owners) v Manzanilli II (owners) (2004) EWCA Civ. 1007.

7 The point has been made, however, that judges and lawyers have paid greater attention to the more prosaic rules of evidence specifying the burden and standard of proof than to the "more grand-sounding constitutional principle of the presumption of innocence": see P. Roberts and A. Zuckerman, Criminal Evidence (2004), p. 327. For an analysis of the privilege against self incrimination in English law and a critique of the human rights jurisprudence in this field, see Lord Justice Sedley, "Wringing out the Fault: Self-Incrimination in the 21 ${ }^{\text {st }}$ Century" (2001) 52 N.I. L.Q. 107.

8 For an analysis of these doctrines, see A.D.R. Zellick and R. J. Sharpe, The Law of Habeas Corpus (2006), A. Choo, Abuse of Process and Judicial Stays of Criminal Proceedings (1994).

9 This is not the first time that questions have been asked about the future of the common law. The growing influence of European Union law and international legal regimes such as the European Convention provoked such questions before the Human Rights Act was enacted. Cf. J. Beatson, "Has the Common Law a Future?" (1997) 56 Camb. L.J. 291 and Lord Goff, "The Future of the Common Law" (1997) 46 I.C.L.Q. 745. For the view, however, that the entire British Constitution including "constitutional statutes" such as the Human Rights Act and the European Communities Act 1972 is underpinned by the common law, see the judgment of 
Dickson points towards this possibility in the conclusion of his lecture when, against the background of a generally positive account of the manner in which the House of Lords has protected human rights in recent years, he laments that there have been a number of instances where the House of Lords has failed to grasp the opportunity to widen the protection of rights beyond what is required by the European Convention. The two examples he gives from the criminal justice field, both pre-dating the Human Rights Act, are the failure to rule that compensation is available to someone wrongfully denied access to a solicitor and the failure to rule that terrorist suspects have a right to have their solicitor present during police interviews. ${ }^{10}$ Although the latter right was subsequently recognised in published codes of conduct, ${ }^{11}$ the ruling that there was no such right at common law is an illustration of what might be regarded in the new human rights era as the limited and static role that the common law is reduced to when faced with a government determined to cut back on civil liberties. ${ }^{12}$ Against the background of the curtailment of the right to silence in Northern Ireland under the Criminal Evidence (Northern Ireland) Order 1988, it was argued by counsel for the appellants that even if it could not be said that the common law recognised a right in every person to have the advice and assistance of a solicitor during police interviews, the House of Lords should now recognise such a right because the curtailment of the right of silence had transformed the landscape of the criminal trial. Delivering the opinion of the House of Lords, Lord Browne-Wilkinson accepted that the attenuation of the right of silence gave some force to the argument that the House should now by analogy with the right to consult a solicitor outside the interview room recognise a right to be accompanied by a solicitor in a police interview. But such an argument could not be divorced from the legislative framework in which Parliament had clearly omitted to provide for such a right for terrorist suspects. It was impermissible for the House to develop the law in a direction which was contrary to the expressed will of Parliament and it was its clearly expressed will that terrorist suspects should not have the right to have a solicitor present during police interviews. His Lordship referred to the recently decided case of Murray v United Kingdom $^{13}$ in which the European Court of Human Rights ruled that it was a breach of an accused's right to a fair trial for a court to draw inferences from an accused's silence under police questioning when he had been denied access to a solicitor. But the Court had declined to rule whether a refusal to allow a solicitor to be present during police interviews violated article 6 . The clear message from the House of Lords in the pre-Human Rights Act landscape was that if there was to be recognition of a right to have a solicitor present during police questioning, accused persons would have to seek a ruling from Strasbourg and there could be no reliance on the common law.

Laws LJ in Thoburn v Sunderland City Council [2002] EWHC 195 (Admin) and the commentary in M. Elliott, "Embracing Constitutional Legislation: Towards Fundamental Law" (2003) 54 N.I.L.Q. 25.

10 See respectively Cullen v Chief Constable of the RUC [2003] 1 WLR 1763 and $R$. $\mathrm{v}$ Chief Constable of the RUC, exp. Begley, $R \mathrm{v}$ McWilliams [1997] 1 WLR 1475.

11 See Northern Ireland Office, Terrorism Act 2000 (Section 99) Code of Practice (2001), s.6.7.

12 For commentary on this case, see S. Doran and J. Jackson, "Evidence", All E R Annual Review 1997, pp.218 - 219.

13 (1996) 22 EHRR 29. 
What will be argued in this article, however, is that despite or, perhaps more accurately, because of the enactment of the Human Rights Act there is still an important role for the common law to play in the protection of our rights and freedoms. One of the interesting developments to have taken place in criminal justice in recent years has been the increase in the number of oral judicial proceedings that must be conducted in order to determine whether prisoners should be released. ${ }^{14}$ Human rights jurisprudence has been instrumental in shaping this development towards a fairer process for prisoners but it will be shown that in certain judgments judges have chosen to rely on the common law and not on human rights standards and jurisprudence as the basis for their rulings. Using these developments as an example, it will be argued that the role that the common law has played in the new Human Rights Act era is far from marginal. Just as years ago the common law played a significant role in informing the delineation of the human rights to be found in the European Convention on Human Rights, so today it can play a dynamic role in helping to inform and develop human rights jurisprudence.

\section{The Continuing Dynamism of the Common Law}

One of the best examples of the role that the common law is continuing to play in protecting rights in the new human rights era is to be found in a case which is not about criminal justice at all. In $A$ and others v Secretary of State for the Home Department ${ }^{15}$ the House of Lords had to rule on whether the Special Immigration Appeals Commission (SIAC) hearing an appeal under section 25 of the Anti-terrorism, Crime and Security Act 2001 could rely on evidence that may have been procured by torture inflicted by officials of a foreign state without the complicity of the British authorities. Although the appellants argued that a negative answer was dictated by article 6 of the European Convention of Human Rights, by the principles of public international law and by the common law of England, their Lordships considered that the principles of common law standing alone compelled such an answer. ${ }^{16}$

The Secretary of State argued that since there was no restriction on the information that the Secretary of State could consider in forming a belief or suspicion that a person's presence in the UK was a risk to national security or that he was a terrorist and the function of SIAC was also to decide whether there were reasonable grounds for such a belief or suspicion, an exclusionary rule would produce a mismatch between the evidence the Secretary of State could rely on and the evidence which SIAC could rely on. In addition Rule 44(3) of the Special Immigration Commission (Procedure) Rules 2003 provided that the Commission may receive evidence that would not be admissible in a court of law. Their Lordships, however, considered

14 See generally S. Livingstone, T. Owen and A. MacDonald, Prison Law (2003, $3^{\text {rd }}$ ed). For the impact this has had on the Parole Board in England and Wales, see N. Padfield, "The Parole Board in Transition" [2006] Crim. L.R. 3.

15 [2005] UKHL 71.

16 Although Lord Bingham added: “. . . the principles of the common law do not stand alone. Effect must be given to the European Convention which itself tales account of the all but universal consensus embodied in the Torture Convention." (para.52). 
that the Commission's function was a judicial one and not an executive one. According to Lord Hoffmann, Parliament in setting up a court to review the question whether reasonable grounds existed for suspicion or belief was expecting the court to behave like a court. In the absence of a clear express provision to the contrary, that would include the application of the standards of justice which have traditionally characterised the proceedings of English courts and this excluded the use of evidence obtained by torture, whatever might be its source. The rejection of torture by the common law not only had special iconic importance as the touchstone of a human and civilised legal system, its rejection also had a constitutional resonance for the English people in their historic struggle to make government subject to law.

Although a number of their Lordships were content to take the view that the common law as it stood forbade the reception in evidence of any statement obtained by the use of torture, it was difficult to point to a specific ruling which gave such wholesale expression to the inadmissibility of such evidence under all circumstances. Lord Carswell considered that such a principle may well be justified historically but even if it required some expansion of the common law he was of the clear opinion that the principle could be accommodated. In a strong expression of the continuing dynamism of the common law which is particularly relevant to the argument of this article, his Lordship declared in a passage that is worth quoting in full: ${ }^{17}$

"We have long since ceased to give credence to the fiction that the common law consists of a number of pre-ordained rules which merely require discovery and enunciation. Two centuries ago Lord Kenyon recognised that in being formed from time to time by the wisdom of man it grew and increased from time to time with the wisdom of mankind: $R \mathrm{v}$ Lord Rusby (1800) Pea (2) 189 at 192. Sir Frederick Pollock referred in 1890 in his Oxford Lectures, p.111 to the 'freshly growing fabric of the common law' and McCardie J spoke in Prager v Blatspiel, Stamp and Heacock Ltd [1924] 1 KB 566 and 570 of the demand of an expanding society for an expanding common law. Similarly, in the US Supreme Court 121 years ago Matthew J said in Hurtado v California (184) 110 US 516 at 531 that:

'as it was the characteristic principle of the common law to draw its inspiration from every fountain of justice, we are not to assume that the sources of its supply have been exhausted. On the contrary, we should expect that the new and various experiences of our own situation and system will mould and shape it into new and not less useful forms.'

"As Peter du Ponceau said of the common law (A Dissertation on the Nature and Extent of the Jurisdiction of the Courts, (1824), Preface):

'Its bounds are unknown, it varies with the successions of ages, and takes its colour from the spirit of the times, the learning of the age, and the temper and disposition of the

17 ibid., para.152. 
Judges. It has experienced great changes at different periods, and is destined to experience more. It is by its very nature uncertain and fluctuating, while to vulgar eyes it appears fixed and stationary."”

Lord Carswell concluded that whether or not it has ever been affirmatively declared that the common law declines to allow the admission of evidence obtained by the use of torture, it is quite capable now of embracing such a rule. If that was an extension of the existing common law, it was a modest one, a necessary recognition of the conclusions which should be drawn from well established principles.

The question whether the common law could be extended to forbid the reception of any statement obtained by torture is reminiscent of an old debate which took place when Northern Ireland was in the throes of conflict and violence in the early $1970 \mathrm{~s}$ as to whether the courts could extend the common law concept of an involuntary confession to exclude evidence obtained by any oppressive conduct or oppressive circumstances. The Diplock Commission which was established by the British Government to make recommendations on how to combat the upsurge in violent activity appeared to criticise the Northern Ireland courts for ruling that any interrogation set-up which makes it more likely that those who do not want to speak will eventually do so rendered inadmissible any confession subsequently made. ${ }^{18}$ The suggestion appeared to be made that the courts had failed to exercise a discretion to admit involuntary statements in the emergency situation that existed in Northern Ireland at that time. Yet as Desmond Greer made clear in an article in this Journal at the time, ${ }^{19}$ the Northern Ireland courts had no such discretion as it was a rule of common law that involuntary confessions had to be excluded as evidence. The only question was whether it was legitimate to extend the common law rule to include confessions obtained in oppressive circumstances and Greer demonstrated that there was support for the view that it could. It was the insistence by the Northern Ireland courts that the common law rules be so strictly adhered to that led Parliament on the recommendation of the Diplock Commission to amend the law so that the admissibility of confessions should no longer depend on the principle of voluntariness but instead on the absence of torture, inhuman or degrading treatment, a standard which was derived from article 3 of the European Convention. ${ }^{20}$ This serves as an interesting example of how human rights standards were invoked in order to lower the safeguards of the common law. ${ }^{21}$

18 Diplock Commission, Report of the Commission to consider legal procedures to deal with terrorist activities in Northern Ireland (1972), Cmnd. 5185, para.83. Although the report did not name the decision, it was clearly referring to $R \mathrm{v}$ Flynn and Leonard [1972] NIJB (May).

19 D. S. Greer, "Admissibility of Confessions and the Common Law in Times of Emergency" (1973) 24 N.I.L.Q. 199.

20 See s.6 of the Northern Ireland (Emergency Provisions) Act 1973. This provision survived until 2002 when the PACE test for the admissibility of confessions which superseded the common law voluntariness test was extended to cover persons arrested under the Terrorism Act 2000.

21 The gap opened up between the voluntariness test and the new emergency test was narrowed to some extent, however, by the Northern Ireland courts on occasions 
One issue that divided the Law Lords in the $A$ case was how SIAC should approach the question of the burden of proof on whether a statement had been obtained by torture. Under the Northern Ireland emergency legislation, the accused had first to adduce prima facie evidence that he was subjected to torture or inhuman or degrading treatment and the prosecution had then to satisfy the court that the statement was not obtained in this way. ${ }^{22}$ In the $A$ case the appellants argued that it was for the party seeking to adduce evidence to establish its admissibility if this was challenged. The Secretary of State submitted that it was for the party seeking to challenge the admissibility of evidence to substantiate the factual grounds on which the challenge was based. There was general agreement that a conventional approach to the burden of proof was inappropriate in a proceeding where, as Lord Bingham of Cornhill put it, the appellant may not know the nature or identity of the author of an adverse statement relied on against him, may not see the statement or know what the statement says, may not be able to discuss the adverse evidence with the special advocate appointed to represent his interests and may not know what witnesses to call to rebut assertions of which he is unaware. ${ }^{23}$ Once the issue of torture was raised, the onus passed to SIAC to assess the information and look at the facts in detail. Where their Lordships differed was on the test to be applied in reaching a conclusion. The majority considered that SIAC should refuse to admit the evidence only if positively satisfied that the evidence was obtained by torture while the minority considered that it should refuse to admit the evidence if unable to conclude that there was not a real risk that the evidence had been obtained by torture. Given the difficulties in establishing how such statements have been obtained, however, the majority view risks, as Lord Nicholls of Birkenhead said at the conclusion of his judgment, nullifying the very principle against the admission of evidence procured by torture that their Lordships so unanimously and vigorously supported. ${ }^{24}$

\section{The Common Law Right to an Oral Hearing}

The issue that arose in $A$ as to what standards of justice are appropriate for bodies that have to act as a court has been at the centre of a number of recent judgments involving prisoner releases. In a series of decisions over a number of years, the European Court of Human Rights has held that leaving decisions of risk and dangerousness in the hands of the executive after the punitive element of a life sentence - the so-called tariff period - has been served is in breach of article 5 (4) of the European Convention on Human Rights which prescribes that everyone who is deprived of his liberty shall be

using their common law discretion to exclude confessions which were strictly admissible under the emergency test. For discussion of this further use of the common law to promote the interests of justice within the framework of the emergency laws, see D. S. Greer, "The Admissibility of Confessions under the Northern Ireland (Emergency Provisions) Act" (1980) 31 N.I.L.Q. 205, J. Jackson, Northern Ireland Supplement to Cross on Evidence (5 ${ }^{\text {th }}$ ed.) (1983), pp.151-154 and J. Jackson and S. Doran, Judge without Jury: Diplock Trials in the Adversary System (1995), pp.37-38. The discretion was later given a statutory footing under s.11(3) of the Northern Ireland (Emergency Provisions) Act 1978.

22 Section 6(2) of the Northern Ireland (Emergency Provisions) Act 1973.

23 [2005] UKHL 71, para.55.

24 ibid., para. 80. 
entitled to take proceedings by which the lawfulness of his detention shall be decided speedily by a court. ${ }^{25}$ As a result of the landmark decision in $R \mathrm{v}$ Secretary of State for the Home Department ex $p$ Anderson, ${ }^{26}$ all mandatory as well as determinate life sentence prisoners in the UK became entitled after the expiry of their tariff to an oral hearing. But if the European Convention provided the momentum for this particular decision, the House of Lords decision in $R$ (on the application of Smith) v Parole Board; $R$ (on the application of West) v Parole Board ${ }^{27}$ relied on the common law to extend the principle of an oral hearing to other categories of prisoners challenging the revocation of their licence.

In Smith and West two prisoners were recalled to prison on the ground that each had breached the conditions of his licence. In each case the Parole Board considered the appellant's written representations but rejected them and the issue before the House of Lords was whether the appellants should have been offered an oral hearing. Under section 32 of the Criminal Justice Act 1991, when considering whether to release prisoners after the revocation of their licences, the Parole Board was permitted to hold an oral hearing (in the form of an interview by a Parole Board member) if it thought it necessary or desirable to do so but was not expressly required to do so. The greater part of the argument in the appeals centred on whether there had been compliance with articles 5 and 6 of the European Convention. Their Lordships expressed no clear view as to the applicability of article 6 but agreed that the protection offered by article 5(4) came within the ambit of licence revocation cases because article 5(4) conferred a right on a prisoner to have his detention lawfully reviewed by a court when a new situation of detention arose for the prisoner, as it did when his licence was revoked. The difficulty was that article 5(4) says little about how a court should conduct these proceedings. Although their Lordships made some reference to the European authorities on what was required by article 5(4), ${ }^{28}$ they chose to read the common law requirements of procedural fairness into article 5(4). The Parole Board's review of the decision to revoke a prisoner's licence satisfied the requirements of article 5(4) provided it was conducted in a manner which met the requirements of procedural fairness. According to Lord Hope of Craighead, although procedural fairness was not a requirement of article 5(4) it was built into the convention requirement because article 5 (4) required that the continuing detention must be judicially supervised and under domestic common law bodies acting judicially must conduct their proceedings in a way that was procedurally fair. ${ }^{29}$

25 See, e.g. Thynne, Gunnell and Wilson v United Kingdom (1991) 13 EHRR CD 135, Hussain v United Kingdom (1996) 22 EHRR 1, Stafford v United Kingdom (2002) 35 EHRR 32.

26 [2002] UKHL 46.

27 [2005] UKHL 1.

28 Lord Bingham referred to a number of European cases where the European Court considered that the possibility of a detainee being heard in person or through some form of representation had been recognised as a fundamental procedural guarantee in matters of deprivation of liberty: see, e.g. De Wilde v Belgium (No 1) (1971) 1 EHRR 373 at 407 (para.76), Winterwerp v Netherlands (1979) 2 EHRR 387 at 409 (para.60), Sanchez-Reisse v Switzerland (1987) 9 EHRR 71 at 83 (para.51).

29 [2005] UKHL 1, para.75. 
The Parole Board did not dispute that it had to act in a procedurally fair manner and accepted that in some cases, as where there is a dispute on an issue of fact material to the outcome, procedural fairness may require it to hold an oral hearing at which the issue may be contested. But it resisted the view that there should be any presumption in favour of an oral hearing in these cases. In order to determine what was procedurally fair, their Lordships considered that account must be taken of the interests at stake. According to Lord Bingham: ${ }^{30}$

"On one side is the safety of the public with which the Parole Board cannot gamble . . . On the other is the prisoner's freedom. This is a conditional, and to that extent precarious freedom. In Weeks v UK (1988) 10 EHRR 293 at $307-308$ (para 40), the European Court of Human Rights . . . recognised the freedom enjoyed by a discretionary life sentence prisoner as 'more circumscribed in law and more precarious than the freedom enjoyed by the ordinary citizen' but as, none the less, a state of liberty for the purposes of art 5 of the convention. The value of freedom to a prisoner, even when conditional, was acknowledged by the Supreme Court of the United States in Morrissey v Brewer (1972) 408 US 471 (para.12) and by Dickson J, dissenting (although not on this point), in the Supreme Court of Canada in Howarth v National Parole Board (1974) 50 DLR (3d) 349 at 358."

His Lordship considered that while an oral hearing was most obviously necessary to achieve a just decision in a case where facts are in issue which may affect the outcome, there were other cases in which an oral hearing may well contribute to achieving a just decision. His Lordship went on to quote from a passage in the United States Supreme Court case of Goldberg v Kelly ${ }^{31}$ where Brennan $\mathrm{J}$ said that oral presentations permitted the recipient to mould his argument to the issues the decision maker appeared to regard as important in a manner that was not possible with written submissions. Although, in Lord Bingham's view, the common law duty of procedural fairness did not require the Parole Board to hold an oral hearing in every case where a determinate prisoner resists recall if he does not decline the offer of such a hearing, the duty should not be as constricted as it had hitherto been held in previous rulings. Even if important facts were not in dispute, they may be open to explanation or mitigation or may lose some significance in the light of other new facts. While the Parole Board's task was to assess risk, it may be greatly assisted in discharging it by exposure to the prisoner or the questioning of those who have dealt with him. It may often be very difficult to address effective representations without knowing the points which are troubling the decision maker. The prisoner should have the benefit of a procedure which fairly reflects, on the facts of his particular case, the importance of what is at stake for him.

As in the $A$ case, it is not entirely clear whether their Lordships were stating what the common law required in these circumstances or whether they were adopting an expansive interpretation of the common law. What is clear is that

30 ibid., para.30.

31 (1970) 397 US 254 at 269. 
they were giving a more expansive interpretation of what procedural fairness required than had been considered necessary by the Court of Appeal and by previous rulings. Their Lordships did not require an oral hearing in every case where a prisoner has had his licence revoked. But as David Pannick has argued, given that the liberty of the prisoner is a matter on which there is much at stake both for the prisoner and society, it is difficult to see that there will be many cases where denial of an oral hearing is consistent with the principle of fairness when the Board is minded to require the prisoner to remain in custody and the prisoner asks for a hearing. ${ }^{32}$ Pannick concluded by saying that "as is the way with the common law, in a few months the novel principle stated by the House of Lords will ... have become orthodox practice". ${ }^{33}$

The case also serves as an example of the way in which the courts can use the common law to put flesh on the bones of rather general and uncertain human rights standards. Although article 5(4) requires the lawfulness of a person's detention to be decided by a court, it has been unclear what procedures should govern such a "court". In some instances the European Court has ruled that the right to be heard is a fundamental procedural guarantee in matters of liberty but the scope of this right has not been altogether clear. ${ }^{34}$ The common law was therefore able to be used to establish more clearly what the bounds of such a right were. Common law rights and convention rights have different roots. As Lord Hope said, ${ }^{35}$ the introduction of Convention rights into domestic law by the Human Rights Act provides a minimum standard of human rights protection. But it does not restrict any other right or freedom which the law confers and this is where the common law is able to step in and impose those conditions of procedural fairness that it requires of a court. Both sets of rights are therefore able, as Lord Hope put it, to "inform" each other. ${ }^{36}$ The Convention informs the common law as it is the Convention which requires there to be a judicial review of detention in the first place but the common law in turn is able to inform the Convention through its requirement of procedural fairness.

\section{The Common Law Right to Disclosure of Information}

If Smith and West represents to date the high water mark of common law protection in the context of prisoner release cases, two more recent decisions of the House of Lords raised questions as to how much further the common law principle of procedural fairness should be extended in such cases. The certified issue in Roberts $v$ Parole Board ${ }^{37}$ was whether the Parole Board was able within the powers granted by the Criminal Justice Act 1991 and compatibly with article 5 of the Convention to withhold material relevant to the appellant's parole review from the appellant's legal representatives and instead to disclose that material to a specially appointed advocate who would represent the appellant in the absence of the appellant and his legal

32 D. Pannick, Parole Board Annual Lecture, 6 April 2005, available at www.paroleboard.gov.uk

33 ibid., p.8.

34 See S. Trechsel, Human Rights in Criminal Proceedings (2005), pp.482-3.

35 [2005] UKHL 1, para.73.

36 ibid., para.74.

37 [2005] UKHL 45. 
representative at a closed hearing. A similar issue arose in $R e$ McClean ${ }^{38}$ decided by the House on the same day as Roberts in the somewhat different context of a hearing established to determine whether a prisoner was entitled to accelerated release under the scheme for prisoner release agreed under the terms of the Belfast Agreement. The panel of sentence review commissioners in this case had revoked a declaration of eligibility for release made in McClean's favour after an incident while he was on prerelease from prison. In the course of the hearing the panel had granted an application from the Secretary of State to rely on secret intelligence information which was not disclosed to the prisoner and had applied for a special advocate to represent his interests. The case raised important issues as to whether articles 5 and 6 of the Convention applied to this particular prisoner release scheme and issues as to what procedural fairness required under this scheme but in the event the Law Lords did not need to decide these questions as they considered that the procedures did not in fact work unfairness to McClean in the instant case. He had been given the gist of the case against him and the commissioners had declared that they had taken no account of the damaging information submitted by the Secretary of State because it was not necessary to do so to reach its decision.

In Roberts the appellant, a prisoner whose tariff period of 30 years for the murder of three unarmed police officers expired in 1996, was moved from an open prison to a closed prison in 2000 apparently on the basis of alleged breaches of trust committed by him while he was held in open conditions. The Parole Board ruled that certain "sensitive material" should be withheld from the appellant on the grounds that the safety of the source of the information would be at risk if the material was disclosed and that the material should be disclosed instead to a specially appointed advocate. The Court of Appeal and the House of Lords were not required to rule on whether this proposed procedure was unfair to the appellant. The question was a narrower one as to whether as a matter of principle the special advocate procedure could ever be adopted.

As in Smith and West a core argument centred upon what was required under article 5(4) of the Convention given that the appellant had a right under this article to have his detention reviewed by a court. But again, as in Smith and West, their Lordships drew more strongly upon principles of common law procedural fairness than upon European jurisprudence in deciding what was required under article 5(4). At stake here was the fundamental principle of judicial process that a party is entitled to the disclosure of all materials which may be taken into account by the court when reaching a decision adverse to that party. Their Lordships agreed that the use of the special advocate procedure could never, as Lord Woolf put it, ${ }^{39}$ be a "panacea" for the grave disadvantages of a person not being aware of the case against him. There appeared to be some difference of emphasis, however, between their Lordships as to just how debilitating such a procedure could be. Lord Woolf considered that the use of such a procedure could mitigate these disadvantages. A special advocate could persuade the tribunal that there could perfectly properly be disclosure subject to no restrictions. The

38 [2005] UKHL 46.

39 [2005] UKHL 45, para.60. 
advocate may be able to destroy the credibility of a witness whose evidence is not disclosed. Although the advocate could not communicate with the prisoner, in appropriate circumstances he may be authorized to communicate with his legal representative or he may receive useful information before he has been instructed. Other Law Lords appeared to be less sanguine about the ability of a special advocate to mitigate the disadvantages of not knowing the case against one. Although Lord Rodger of Earlsferry did not consider the analogy apposite, ${ }^{40}$ Lord Carswell and Lord Steyn considered that the prisoner against whom unfounded allegations have been made is in a "Kafkaesque" situation. ${ }^{41}$ According to Lord Carswell, he may be altogether in the dark about the allegations made and unable to divine what they may be and give instructions about rebutting them. ${ }^{42}$ The special advocate was necessarily limited in the steps which he can take to challenge them bearing in mind his inability to take instructions from the prisoner. Lord Steyn was the strongest in his criticism of the special advocate procedure: ${ }^{43}$

"Once the special advocate becomes aware of the case against the prisoner he may not divulge that information to the prisoner. It is not to the point to say that the special advocate procedure is 'better than nothing'. Taken as a whole, the procedure completely lacks the essential characteristics of a fair hearing. It is important not to pussyfoot about such a fundamental matter: the special advocate procedure undermines the very essence of elementary justice. It involves a phantom hearing only."

Although their Lordships expressed somewhat different views as to how debilitating the special advocate procedure could be to the presentation of the prisoner's case, the ultimate question was whether the Parole Board had the power to authorise such a procedure and on this question their Lordships were more seriously split. Unlike the statutory schemes in Northern Ireland for the release of paramilitary prisoners and life sentence prisoners, ${ }^{44}$ the Parole Board was not given an express power to adopt such a procedure either under primary legislation or under its rules of procedure. Lord Bingham and Lord Steyn took the view that in the absence of such an express power it was not lawful for the Parole Board to depart from the ordinary rules of procedural fairness. According to Lord Bingham, ${ }^{45}$ the fact that Parliament had made provision in other situations for the use of the special advocate procedure showed that if Parliament intends to depart from the ordinary rules of procedural fairness, it legislates to confer such a power in clear and express terms. According to Lord Steyn, ${ }^{46}$ the special advocate

ibid., para.110..

41 ibid., paras.95, 126.

42 ibid., para. 126

43 ibid., para.88.

44 See in relation to the paramilitary release scheme, the Northern Ireland (Sentences) Act 1998, Sch.2. In Northern Ireland the release of life sentence prisoners is governed by the Life Sentences (Northern Ireland) Order 2002, Sch.2 to which empowers the Secretary of State to make rules to withhold evidence from a prisoner and provides for the appointment of a special advocate.

45 [2005] UKHL 45, para.30.

46 ibid., para.93. 
procedure struck at the root of the prisoner's fundamental right to a fair procedure; if such a departure were to be introduced it had to be done by Parliament. ${ }^{47}$

The other Law Lords, however, took the contrary view that in order to meet its statutory obligations the Board was empowered to take steps in exceptional circumstances to authorize the special advocate procedure. Under paragraph 1(2)b of Schedule 5 to the Criminal Justice Act 1991 the Board had the power to do "such things and enter into such transactions as are incidental to or conducive to the discharge of its functions". The Board had a particular statutory duty under section 28(6) of the Crime (Sentences) Act 1997 not to release a life prisoner unless it was satisfied that it was no longer necessary for the protection of the public that the prisoner should be confined. In order to discharge this function it was essential that it had before it all material information necessary for the determination of this issue of public safety and if, as Lord Carswell put it, ${ }^{48}$ the only effective way to get that information from reluctant informants was to use the special advocate procedure then the use of that procedure was incidental to or conducive to the discharge of its functions.

Two questions arise from the reasoning of the majority. First, what then is the status of the common law principle of disclosure? Lord Woolf specifically endorsed the declaration in Smith and West that the prisoner should have the benefit of a procedure which fairly reflects the importance of what was at stake for him as for society. ${ }^{49}$ But their Lordships spoke of a "triangulation" or "triumvirate" of interests that had to be taken into account by the Parole Board in executing its statutory duty - the interests of the prisoner, the interests of society and, as part of this obligation, the interests of third parties who may be at risk if their evidence is disclosed to the Parole Board. ${ }^{50}$ Lord Woolf accepted the submission of the appellant's counsel that there is at common law and under article 5(4) a core, irreducible minimum entitlement for a prisoner to be able effectively to challenge any evidence which decisively bears on the legality of his detention. ${ }^{51}$ But the question was what that minimum was and here a balancing test had to be carried out to determine whether the minimum was crossed. As this was an appeal based on a matter of principle, their Lordships could not properly perform that balancing procedure in the case before them, but, according to Lord Woolf, they could not determine the matter of principle on the basis that there were no circumstances in which there could be no disclosure of any evidence which decisively bears upon the legality of the prisoner's detention which would justify the appointment of a special advocate.

47 There are a number of examples where the courts have invoked the interpretative presumption that fundamental rights may only be interfered with where primary legislation expressly or by necessary implication authorises the interference. See, e.g. Raymond $\mathrm{v}$ Honey [1982] 1 All ER 756, $R$ v Home Secretary ex p. Leech (No 2 [1993] 4 All ER 539 and $R$ v Lord Chancellor, ex p. Witham \{1998] QB 575.

48 [2005] UKHL 45, para.131.

49 ibid., para.46.

50 "Triangulation of interests" is the term used by Lord Woolf, ibid., at para.48 and by Lord Carswel1 at para.128. "Triumvirate of interests" is the term used by Lord Woolf at para.76.

51 [2005] UKHL 45, para.68. 
Earlier in his judgment, Lord Woolf referred to Lord Bingham's judgment in $R \vee H^{52}$ where his Lordship considered that there could be some derogation from the golden rule of full disclosure in order to protect the public interest in the investigation of crime and considered it could be justified to appoint a special advocate in exceptional circumstances. Although in $H$ Lord Bingham was considering whether such a procedure was compatible with the accused's right under article 6 to a fair trial, his statements were, in Lord Woolf's view, ${ }^{53}$ even more apposite in the context of a hearing where issues of guilt or innocence were not at stake and where although the decision was of the greatest importance to the prisoner, it was not one that was irreversible. In $H$ Lord Bingham had said that "fairness is a constantly evolving concept" and that it was important to recognise that "standards and perceptions of fairness may change, not only from one century to another but also, sometimes, from one decade to another." 54 Lord Bingham's response at the end of his judgment in Roberts was that the issue in $H$ could be distinguished from that which had to be determined in Roberts. ${ }^{55}$ In $H$ the House held that a special advocate might exceptionally be appointed in a criminal case to help resolve an issue whether a trial could be fairly conducted if material favourable to the defendant were not disclosed to him. It was not suggested that any part of the prosecution case against the defendant could be properly withheld from the defendant and his legal representative. Although the issues were different in each case, Lord Bingham's reference to fairness as an evolving concept is an illustration of how the common law can be adapted to deal with changing circumstances. ${ }^{56}$ If the Smith and West case is an example of the common law principle of procedural fairness evolving to take full account of the need to hear prisoners when matters of liberty are at stake, Roberts is an example of the principle adapting to the need for the Parole Board to carry out its statutory obligation. The question here is whether their Lordships took full enough account of the fact that although charged with carrying out a statutory duty, the Parole Board has for the purposes of article 5(4) of the Convention to operate as a judicial body and to comply with the principles of fairness that are consonant with a judicial body.

This leads on to the second question which is how the majority judgments can be reconciled with the human rights duty under article 5(4) for the body reviewing the detention of the prisoner to act as a court. There were earlier rulings of the European Court set out by Lord Carswell in his judgment where the Court had held that the inability to challenge the prosecution case

[2004] 2 AC 134.

33 [2005] UKHL 45, para.42.

54 [2004]2 AC 134, para.11.

55 [2005] UKHL 45, para.31.

56 See also Lloyd v McMahon [1987] AC 625, 702 where Lord Bridge of Harwich commented that "the so-called rules of natural justice are not engraved on tablets of stone. To use the phrase which better encapsulates the underlying concept, what the requirements of fairness demand when any body, domestic, administrative, or judicial, has to make a decision which will affect the rights of individuals depends upon the character of the decision making body. The kind of decision it has to make and the statutory or other framework in which it operates." 
in various respects constituted a breach of article 5(4). ${ }^{57}$ Lord Carswell referred to Lord Bingham's statement in $H^{58}$ that the consistent practice of the Strasbourg court has always been to declare principles and apply these on a case by case basis according to the particular facts of the case but to avoid laying down rigid or inflexible rules. ${ }^{59}$ He also referred to Lord Bingham's statement in Brown v Stott ${ }^{60}$ that the court pays very close attention to the facts of particular cases coming before it and recognizes that there is always a need for a fair balance between the general interest of the community and the personal rights of the individual. In this case their Lordships had to balance competing interests on the question of principle as to whether a prisoner could ever be denied sufficient knowledge of the allegations made against him and a special advocate appointed to represent his interests. On this question Lord Carswell considered that the interests of the informant and the public must prevail over those of the prisoner, although he stressed that the use of the special advocate procedure should be rare and exceptional and he accepted that there could well be cases in which it would not be sufficiently fair for such a procedure to be used. ${ }^{61}$

Lord Bingham's view of how the European Court has perceived its balancing role in relation to article 6 of the Convention has been criticized on the ground that the Court has not consistently applied such a broad balancing approach. ${ }^{62}$ A similar criticism could be made of the way in which Lord Carswell characterized the manner in which competing interests should be balanced for the purposes of article 5(4). But however the Court has perceived its balancing role, the case by case approach of the Court has limited the manner in which it has been able to develop its jurisprudence. The European Court has rarely determined issues of principle of the kind which their Lordships had to consider in Roberts. Instead it has had to approach cases on the basis of whether in the particular circumstances of each case before it the proceedings as a whole upheld the standards of fairness required under article 6 or under article 5(4). This points, as Lord Carswell said, ${ }^{63}$ to a difference of approach between the manner in which the European Court and our domestic courts decides cases and illustrates a problem with drawing too heavily on the Strasbourg jurisprudence.

The difference can be illustrated in the judgment of Lord Bingham. Although his Lordship considered that the special advocate procedure that the Parole Board proposed to adopt in resolving the appellant's parole review infringed the basic principles of common law and considered that these principles could not be overridden without an express power given to it by Parliament, his Lordship felt unable to rule that the adoption of this procedure was necessarily incompatible with article 5(4). In view of the

57 Lamy v Belgium (1989) 11 EHRR 529, Nikolova v Bulgaria (1999) 31 EHRR 64, Garcia Alva v Germany (2001) 37 EHRR 335.

58 [2004] 2 AC 134, para.33.

59 [2005] UKHL 45, para.140.

60 [2003] 1 AC 681, 704.

61 [2005] UKHL 45, para.144.

62 See A. Ashworth, Human Rights, Serious Crime and Criminal Procedure (2002), Hamlyn Lectures. See also A. Ashworth and M. Redmayne, The Criminal Process ( $3^{\text {rd }}$ ed., 2005), pp.41-42.

63 [2005] UKHL, para.140. 
"dramatic impact of deprivation of liberty on the fundamental rights of the individual", ${ }^{64}$ his Lordship doubted whether a decision of the Board adverse to the appellant based on evidence not disclosed to him which neither he not his legal representatives has had an opportunity to challenge could be held to meet the fundamental duty of procedural fairness required by article 5(4). Lord Steyn for his part appeared to have no hesitation in considering that the "phantom hearing involving a special advocate" could not meet the minimum standards of fairness under art 5(4) and domestic law. ${ }^{65}$ But as Lord Bingham said the practice of the European Court is to consider the proceedings in question as a whole and its judgment was almost necessarily made in retrospect when there is evidence of what actually happened. He continued: 66

"Save where an issue of compatibility turns on a pure question of statutory construction, the House should in my opinion be similarly reluctant to rule without knowing what has actually happened."

In the present context his Lordship went on to say that there were some outcomes where the use of a specially appointed advocate would not offend article 5(4). The Board could reject the sensitive material tested by the special advocate or having heard the material tested it might decline to continue the review unless the sensitive material were disclosed to the appellant's legal representatives or the Board might devise a way of redacting or summarising the sensitive material or the Board might reach a decision without relying on the sensitive material, as indeed happened in McClean. If any of these possibilities materialised, there would not be a violation of article 5 (4).

The sensitivity of the European Court to the facts of each case in applying human rights principles and the retrospective approach which it has adopted points then to a defect in the development of human rights jurisprudence as compared with the common law. It has meant, as Lord Bingham said, that the Court has eschewed rigid and inflexible rules but it has also made it difficult for principles to develop in the same manner as the common law. This suggests that there is a continuing role for the common law in the post Human Rights Act era. Not only can it play a role in developing the principles that are required under the Convention as illustrated in the Smith and West case but as Roberts indicates, cases involving matters of fairness may still have to take autonomous account of common law principles. In Roberts their Lordships disagreed over how far the common law principles of procedural fairness should extend in a context where a body like the Parole Board has a fundamental duty to protect the public from risk. But the continuing relevance of these common law principles was clearly evident in the judgments.

64 ibid., para.19 citing the European Court in Garcia Alva v Germany (2001) 37 EHRR 335, para.39.

65 ibid., para.96.

66 ibid., para.19. 


\section{The Burden of Proof}

The importance of the common law right to a fair decision making process can be further illustrated by the McClean case where there was some doubt expressed as to whether article 5(4) and article 6 of the Convention applied to the accelerated prisoner release scheme. ${ }^{67}$ We have seen that their Lordships did not consider that any unfairness arose from the use of the intelligence information supplied by the Secretary of State as the sentence review commissioners did not take this into account in reaching their decision. A further issue in the case, however, concerned where the burden of proof lay on the question whether the prisoner represented a danger to the public. In reaching their decision, the commissioners had proceeded on the basis that the burden of proof lay on the prisoner to prove that he would not be a danger to the public. On a judicial review of this decision, the Northern Ireland High Court concluded that it was neither unfair nor disproportionate to require $\mathrm{Mr}$ McClean to establish on the balance of probabilities that he would not be a danger to the public. But the Northern Ireland Court of Appeal in a majority decision considered that the commissioners should not have placed an onus on the prisoner to prove that he would not be a danger to the public if released immediately. The House of Lords reversed the decision of the Court of Appeal and held that there was no error of principle in the Commissioners' approach.

A number of their Lordships, however, questioned the aptness of speaking of a burden on the prisoner on this question. In the Northern Ireland Court of Appeal McCollum LJ had considered that it was inappropriate to place a burden of proof on the prisoner because the conclusion whether someone is a danger to the public was in the nature of an "opinion or impression" and not the establishment of a fact that either party could be asked to prove. ${ }^{68}$ In his judgment Lord Carswell agreed that this question was a pure exercise of judgment: ${ }^{69}$

“. . . more akin to many administrative decisions than the ordinary judicial process of deciding whether a matter requiring proof has been established. Decisions of the latter type require sufficient evidence to be adduced by the party who wishes to establish it, and if he does not succeed in doing so it may properly be said that he has failed to discharge the burden resting upon him. Although the prisoner obviously wants the Commissioners to find that the conditions have been established, it is not a lis inter partes, and it is not the function of the Secretary of State to prove the case for keeping him in custody.

67 Although some Law Lords considered it was unnecessary to express a view on this question as the prisoner had not suffered any unfairness at the hands of the sentence review commissioners, a view was expressed by Lord Scott of Foscote that art.5(4) was not relevant to the proceedings because the prisoner's human rights did not entitle him to any early release scheme ([2005] UKHL 46, paras.51 and 52). Lord Brown of Eaton-under-Heywood considered there was "force" in this view (para.105).

68 [2004] NICA 14, para.77.

69 [2005] UKHL 46, para.73. 
Support for this view could be found in the observation of Lord Bingham in $R \vee$ Lichniak $^{70}$ when he said of the Parole Board that he doubted whether there was a burden on the prisoner to persuade the Parole Board that it was safe to recommend release, since this was an "administrative process requiring the board to consider all the available material and form a judgment". It followed that it was the duty of the commissioners to conduct a full review of the case without imposing a burden of proof either on the prisoner or on the Secretary of State, their object being to determine whether in their opinion the conditions required to be satisfied for release remain satisfied.

This approach is reminiscent of that adopted by the majority in Roberts in considering how the Parole Board should carry out its statutory functions. Although a "court" when it is conducting a review of detention for the purpose of article 5(4), the Parole Board does not operate on the basis of an adversarial procedure whereby it is for one party to prove matters of risk to the satisfaction of the board. The Board itself has a statutory function to satisfy itself whether a prisoner is any longer a danger to the public. Although it may be a misnomer to speak of a burden of proof in the conventional sense, however, Lord Bingham acknowledged in his judgment in McClean, as he had done in Lichniak, that in the last resort any reasonable doubt which the commissioners properly entertain whether if released immediately, a prisoner would be a danger to the public must be resolved against the prisoner. ${ }^{71}$ While this may be the correct approach in the context of the accelerated release scheme in Northern Ireland where prisoners had no expectation of release under human rights law, the question remains whether this is the correct approach in the context of a life sentence prisoner who is entitled to have the lawfulness of his detention reviewed after the tariff period has expired.

Lichniak was distinguished in $R$ (on the application of Sim) v Parole Board and another ${ }^{72}$ which was an extended sentence case in which the prisoner had been recalled to prison during the extended licence period. Like the judge below, Keene LJ considered that whereas the objective of the sentencing court which imposes an indeterminate sentence is that a person is not to be released unless and until it can be shown that he no longer presents a danger to the public, in an extended sentence case the object of the sentence is not to subject the prisoner to detention for the extended licence period but rather to manage the risk in the community rather than in prison albeit that it is recognised that it may be necessary to resort to further detention if that aim fails. As he put it, "The offender is not on licence as an alternative to prison; rather he is on licence as an alternative to liberty" ${ }^{73}$ The Court of Appeal then applied section 3 of the Human Rights Act to read and give effect to section 44 of the Criminal Justice Act 1991 in a way which was compatible with article 5(4) of the Convention by requiring the Board to direct the offender's release unless positively satisfied that it was necessary for the protection of the public that he be confined.

70 [2002] UKHL 47, para.16.

71 Para.29.

72 [2003] EWCA Civ. 1845.

73 ibid., para.46. 
This case was decided before Smith and West where it was held that any prisoner who is entitled to have the lawfulness of his detention reviewed by a court for the purposes of article 5(4), is entitled also to a standard of procedural fairness consonant with the interests at stake. It will be recalled that Lord Bingham there said that on the one side there is the safety of the public, with which the Parole Board cannot gamble; on the other the prisoner's freedom. Although a life sentence prisoner is not entitled to unconditional freedom after the period of his tariff is served, his freedom is conditional and to that extent precarious but it is nonetheless a state of liberty to which he is entitled under the Convention if no longer a danger to the public. Even though for the reasons given by Lord Carswell, this should not necessarily impose a burden of proof on any party, it may be argued that because an issue of liberty is at stake (albeit a conditional one) the Parole Board should direct the prisoner's release on the expiry of the tariff period unless positively satisfied that it is necessary for protection of the public that he be confined. This would not diminish the Parole Board's statutory obligation to determine the issue of risk but it would give weight to the principle, arguably as embedded in the heritage of the common law as in human rights law, that when someone becomes entitled to release albeit under conditions then he should be released unless those conditions are not satisfied.

\section{The Right to Cross-Examination}

A final question which has yet to be definitively answered is whether prisoners who are given a right to an oral hearing to have the lawfulness of their detention determined have also a right to cross-examine key witnesses in these hearings. Recent Court of Appeal decisions in England and Wales have failed to give a conclusive answer to this question, although the arguments were framed around the common law as well as human rights law. One of the other arguments made for the prisoner in Sim was that the Board should not have considered hearsay evidence in the oral hearing that was provided for the prisoner after his licence was revoked. It was accepted that the Board could take account of hearsay evidence but it was argued that both in terms of common law fairness and under article 5(4) that the prisoner should have been able to cross-examine witnesses on contested matters of fact and to the extent that he was unable to do so, the evidence in question should not have been taken into account by the Parole Board. Reliance was placed on the decision of the European Court of Human Rights in Hussain v $U K^{74}$ where it was held that where a substantial term of imprisonment may be at stake, article 5 (4) requires an oral hearing in the context of an "adversarial procedure" involving legal representation and the possibility of calling and questioning witnesses. Giving the judgment in the Court of Appeal, Keene LJ did not accept that Hussain was seeking to proscribe the use of hearsay. ${ }^{75}$ Hussain was centrally concerned with the question whether a life sentence prisoner should have been entitled to an oral hearing and the reference to the possibility of calling witnesses was only descriptive of the normal processes of an oral hearing and did not mean hearsay evidence could not be taken into account. He did not believe that the Strasbourg

74 Hussain v UK (1996) 22 EHRR 1, para.60.

75 [2003] EWCA Civ. 1845, para.55. 
jurisprudence added anything of significance to the test of fair procedure required by the common law.

This is another demonstration of the limitations of the Strasbourg jurisprudence as guidance for the resolution of concrete issues. As in other cases discussed in this essay, his Lordship preferred to seek guidance from the common law. There was considerable authority at common law which established that it was not necessarily unfair to admit hearsay even where the deprivation of liberty was at stake. However in an obiter dictum that was to form a central argument in the later case of $R$ (on the application of Brooks) v Parole Board, ${ }^{76}$ his Lordship added that, like the judge below: ${ }^{77}$

". . . I can envisage the possibility of circumstances where the evidence in question is so fundamental to the decision that fairness requires that the offender be given the opportunity to test it by cross-examination, before it is taken into account at all. As so often, what is or is not fair will depend on the circumstances of the individual case."

This statement would appear to be another example of how the courts are developing the common law to take account of what fairness requires within the context of an oral hearing required by human rights law. In Sim the Court dismissed the argument that the prisoner should have been able to cross-examine witnesses on disputed matters of fact on the ground that these matters were not key factors in the Parole Board's decision on the question of risk. But disputed matters of fact were central in the Brooks case where the question was whether the panel should have directed the Secretary of State to produce a reluctant witness who had made serious allegations of rape against the prisoner which had led to his arrest and the revocation of his licence. The case was complicated by the fact that the panel had wrongly taken the view that there was no power to compel the witness to attend. In fact the Board had the power to direct the Secretary of State to arrange for the attendance of witnesses if necessary by obtaining a witness summons from the High Court pursuant to rule 34.4 of the Civil Procedure Rules. No request was made by the prisoner's solicitor for the panel to direct the Secretary of State to issue a witness summons and the majority of the Court of Appeal took the view that the Board was entitled to proceed as it did in the absence of the witness, taking into account all the relevant information that was available including the hearsay evidence. Clarke LJ, however, took the view in a dissenting judgment that if the true legal position had been appreciated it would have been much more likely than not that a summons would have been issued because the panel had made it clear in correspondence before the hearing that they regarded the witness's oral evidence as crucial.

Brooks is a somewhat unsatisfactory case because the panel, and it would seem the parties as well, failed to appreciate the nature of the powers of the Board. Kennedy LJ and Clarke LJ both agreed with Keene LJ's view that there could be circumstances where the evidence is so fundamental that

76 [2004] EWCA Civ. 80.

77 [2003] EWCA Civ. 1845, para.57. The statement derives from the judgment of Elias J in $R$ (Sim) v Parole Board and another [2003] EWHC Admin 152, para.59. 
fairness requires that the offender be given an opportunity to test it by cross examination but the question as to when these circumstances might arise was left unresolved by the case. According to Kennedy LJ, ${ }^{78}$ fairness could require cross examination when there is a witness who is willing to testify. In this case, however, if the witness had been prevailed upon to attend, she would probably have refused to testify and if she did agree to testify she would have been very unlikely to repeat her allegations against the prisoner, as there was evidence that she had tried to withdraw her allegations. Consequently, her evidence would have added very little to what the Parole Board already knew from the documentation to be her position. For their part, Clarke LJ and Wall LJ considered that it was wrong to speculate as to what might have happened if the witness had been required to testify. Clarke LJ considered that the circumstances of this case were such as to fall within the principle stated by Keene LJ. Wall LJ did not specifically endorse Keene LJ's dictum and was uneasy about divorcing the issue of fairness from the function which the Board had to perform. ${ }^{79}$ Although the issue in this case was whether or not the prisoner had raped the complainant, the Board was not conducting a criminal trial and the Board had to balance the hardship and injustice of continuing to imprison a man who is unlikely to cause serious injury to the public against the need to protect the public interest against a man who is not unlikely to cause such injury. In the final balance, however, the Board had to give preponderant weight to the need to protect innocent members against any risk of significant injury.

Wall LJ's reference to the need to consider the Board's statutory duty is one which we have seen featured prominently in the Roberts and McClean cases. As in these cases, questions may be asked as to whether sufficient account was taken of the human rights principle that such proceedings must also operate in a judicial manner. It is clear that this does not require a fully fledged common law trial along conventional adversarial lines. In his judgment Kennedy LJ commented that generally speaking unless a request has been made by or of behalf of one of the parties the chairman of the panel should be slow to direct the Secretary of State to produce a witness for crossexamination, especially if he or she is a witness upon whom the Secretary of State does not intend to rely, because the hearing is going to take place "in the context of an adversarial procedure". ${ }^{80}$ The reference to "the context of an adversarial procedure" would seem to be directly attributable to the European Court of Human Right's judgment in Hussain referred to above. In Sim, as we saw, Keene LJ did not attach much significance to this statement and it is important in any event to bear in mind that the context of adversarial procedure within the European context may be quite different from the notion of adversarialism associated with common law proceedings. ${ }^{81}$ It is hard to see why a body such as the Parole Board with the statutory duty of protecting the public should have any hesitation about directing the Secretary

78 [2004] EWCA Civ. 80, paras.36 and 37.

79 ibid., para.71.

80 ibid., para.33.

81 For an exploration of the meaning of "adversary procedure" within the European context, see J. Jackson, "The Effect of Human Rights on Criminal Evidentiary Processes: Towards Convergence, Divergence or Realignment?" (2005) 68 M.L.R. 737. 
of State to produce a witness where it considers that the witness could give valuable information to the Board and the fact that no request is made by the parties should not deter the Board from doing this. Wall LJ's dictum may best be seen in the context of the facts of the case in hand where the witness was a reluctant witness and it was unclear what good would therefore be served by requiring her to testify. But even where the Board does not believe that a witness may provide further valuable information, the question remains whether fairness should not require that the prisoner be given an opportunity to test the evidence of a crucial albeit reluctant witness where this is requested, provided sufficient protection can be given to the witness in question. It would seem that further clarification is needed on this question.

\section{Conclusion}

This article has argued that the common law still has an important part to play in safeguarding individual rights in the post Human Rights Act era. In arguing thus, I do not wish to minimise the significance of what has been termed the "human rights revolution". 82 Our domestic law must now take account of the requirements of the Convention and we see this in the way in which new principles such as the principle of proportionality are increasingly becoming part of common judicial parlance. In the field of criminal justice, the jurisprudence of the European Court of Human Rights which must be taken into account under the Human Rights Act has played a role in protecting the rights of the defendant in a number of areas. Examples include the constraint which the Court has put upon the manner in which inferences may be drawn from silence under the Criminal Evidence (Northern Ireland) Order 1988 and the strict limits it has set upon departures that are made from the defence right to disclosure of evidence before trial. ${ }^{83}$ It has been argued elsewhere that European procedures must now align themselves to models of proof that are neither traditionally adversarial nor inquisitorial in character. ${ }^{84}$ Although the principles of fair trial set out in the Convention have a distinctly common law hue, the European Court has developed its own autonomous principles of fairness and has departed from the strait jacket of the specific rights contained in article 6 (2) and (3).

But this does not mean that as new procedures are developed there is no role for the common law to play and this can be clearly seen in the postconviction phases of proof that are being developed in prisoner release cases. We have seen that the European Court was responsible through its interpretation of article 5(4) for requiring that judicial hearings are put in place to govern the release of life sentence prisoners but the common law has played a role in extending these to licence revocation cases. In his classic account of the development of pre-trial prosecution procedures in England

82 See C. Harvey, "Governing after the Rights Revolution" (2006) available at www.law.qub.ac.uk/humanrts/hrevents/charvey06.doc.

83 Key judgments on the silence legislation include Murray v United Kingdom (1996) 22 EHRR 29, Condron v United Kingdom (2001) 31 EHRR 1 and Beckles v United Kingdom 200236 EHRR 13. Key judgments on disclosure include Rowe and Davis v United Kingdom (2000) 30 EHRR 1, Fitt v United Kingdom (2000) EHRR 1, Jasper v United (2000) 30 EHRR 1 and Edwards and Lewis v United Kingdom (2005) 40 EHRR 24.

${ }^{84}$ Supra n.81 above. 
and Wales, Lord Devlin once argued that the story was one of a constant drift always in the same direction from unfettered administrative action to regulated judicial proceeding. ${ }^{85}$ We are now witnessing a similar story at the other end of the criminal justice spectrum of a gradual transformation of the procedures governing prisoner releases from executive and administrative action to regulated judicial proceedings. As this story unfolds, human rights jurisprudence and the common law are interacting together to develop a framework as to how these proceedings should operate. ${ }^{86}$ This development is still in a state of evolution and the full story has yet to be completed but what is clear is that the common law rules of procedural farness are playing a part in this jurisprudence.

We have referred already to the passage in Lord Carswell's judgment in the $A$ case highlighting the ability of the common law to adapt to changing circumstances. ${ }^{87}$ After concluding that the common law was quite capable of embracing a rule which forbade the admission of evidence obtained by the use of torture, his Lordship added that it was only right that this should be done in what Tennyson described as: 88

$$
\begin{aligned}
& \text { "A land of settled government } \\
& \text { A land of just and old renown } \\
& \text { Where Freedom slowly broadens down } \\
& \text { From precedent to precedent." }
\end{aligned}
$$

Tennyson wrote these lines after the passage of the Reform Bill of 1832 and they expressed his satisfaction that so revolutionary a measure had been made law by constitutional means without resort to violence. History has shown that Parliament cannot always be relied upon to defend basic fundamental freedoms and the common law has also played an important role in this respect. Now recourse may also be had to international human rights standards. The passage of the Human Rights Act has strengthened this international dimension as domestic courts must give effect to the human rights and fundamental freedoms laid down under the European Convention and take account of the jurisprudence of the European Court of Human Rights. This is an important new development but it should not serve to overshadow the common law. The common law has proved its ability to adapt to changing circumstances over many centuries and it is quite capable of accommodating this new development.

85 P. Devlin, The Criminal Prosecution in England (1960), p.10.

86 This may be seen as an example of what Laws LJ has referred to as a "municipal law of human rights" being developed by the incremental method of the common law taking account of the Strasbourg jurisprudence as the courts are enjoined to do under s.2 of the Human Rights Act: see Runn Begum v Tower Hamlets London Borough Council [2002] 1 WLR 2491, 2500 and $R(M)$ v Commissioner of the Police of the Metropolis [2001] A.C.D. 508.

87 See text at supra n.17.

88 From "You Ask Me, Why" (1842) verse iii. See Poems of Lord Tennyson (1954), 440- 441. 